\title{
Stage IVB Uterine Corpus Endometrial Stromal Sarcoma AJCC v8
}

National Cancer Institute

\section{Source}

National Cancer Institute. Stage IVB Uterine Corpus Endometrial Stromal Sarcoma A/CC v8. NCI Thesaurus. Code C139893.

Stage IVB includes: Any T, Any N, M1. M1: M1: Distant metastasis (excluding adnexa, pelvic, and abdominal tissues). (from AJCC 8th Ed.) 